\title{
FUNGSI PENCATATAN PERKAWINAN DIKAITKAN DENGAN UPAYA PERLINDUNGAN HUKUM TERHADAP ANAK SETELAH PUTUSAN MAHKAMAH KONSTITUSI NOMOR: 46/PUU-VIII/2010
}

\author{
Atikah Rahmi \\ Sakdul \\ Fakultas Hukum Universitas Muhammadiyah Sumatera Utara \\ Email: atikahrahmi@gmail.com
}

\begin{abstract}
Registration of marriage is very important for the parties in the household, as a requirement for recognition or non-recognition of marriage by the state. Registration of marriages provides authentic evidence against a person's legal status through marriage publication book or marriage certificate. Marriages that are not listed will lead the legal status of the parties to the marriage are not clear. Pursuant to Article 43 of Law No. 1 in 1974, the children born of the marriage were not recorded, did not receive judicial protection. Constitutional Court Decision No. 46/PUU-VIII/2010 implicates on changing values in society regarding the status and rights of children outside of marriage. The Constitutional Court makes decision as two sides of a coin. On the one hand protect the rights of children outside of mating, but on the other hand the decision may weaken impressed marriage function and can lead to the institution of marriage becomes less are not sacred.
\end{abstract}

Kata Kunci: Fungsi Pencatatan, Perkawinan, Perlindungan Anak.

\section{A. Latar Belakang}

Wirjono Prodjodikoro (1991: 7), mengatakan bahwa sudah menjadi kodrat alam, bahwa dua orang manusia dengan jenis kelamin yang berlainan, seorang perempuan dan seorang laki-laki, ada daya saling menarik satu sama lain untuk hidup bersama. Dalam hal ini alam pikiran orang tidaklah mesti atau selalu ditujukan pada hal bersetubuh antara dua orang manusia tadi, meskipun pada umumnya dapat dikatakan, hal bersetubuh ini merupakan faktor pendorong yang penting untuk hidup bersama tadi, baik dengan keinginan mendapatkan anak turunannya sendiri, maupun hanya untuk memenuhi hawa nafsu belaka, yang lazim dikenal dengan istilah perkawinan. 
Hidup bersama berakibat sangat penting di dalam masyarakat. Akibat paling dekat, bahwa dengan hidup bersama antara dua orang manusia ini mereka sekedar menyendirikan diri dari anggota-anggota lain dari masyarakat. Akibat lebih jauh ialah kalau kemudian mereka mempunyai anak-anak, dengan anakanaknya itu mereka merupakan keluarga tersendiri.

Berhubung dengan akibat yang sangat penting dari hidup bersama inilah, maka masyarakat membutuhkan suatu peraturan dari hidup bersama ini, yaitu mengenai syarat-syarat untuk peresmian, pelaksanaan, kelanjutan dan terhentinya hidup bersama itu. Peraturan inilah yang menimbulkan pengertian perkawinan, yaitu suatu hidup bersama dari seorang laki-laki dan seorang perempuan yang memenuhi syarat-syarat yang termasuk dalam peraturan tersebut, sehingga terlihat jelas bahwa pengertian perkawinan adalah lepas dari pengertian hidup bersama dipandang dari sudut ilmu biologi.

Literatur ilmu hukum menyebutkan ada berbagai pengertian perkawinan diberikan oleh para ahli yang melihatnya dari sudut pandang berbeda. Seperti yang dijelaskan Sebagai bahan perbandingan, dapat dilihat beberapa defenisi perkawinan yang diberikan para ahli, yaitu:

1. Subekti (1994: 23), mendefinisikan bahwa perkawinan sebagai pertalian yang sah antara seorang lelaki dan seorang perempuan untuk waktu yang lama;

2. Ali Afandi (1997: 94), mendefenisikan bahwa perkawinan sebagai suatu persetujuan kekeluargaan;

3. Soediman Kartohadiprodjo (1984: 36), mendefenisikan bahwa perkawinan adalah suatu hubungan antara orang wanita dan pria yang bersifat abadi;

4. K. Wantjik Saleh (1960: 14), mendefenisikan bahwa perkawinan sebagai ikatan lahir bathin antara seorang pria dan seorang wanita sebagai pasangan suami isteri.

Berdasarkan pendapat-pendapat yang disebutkan di atas dapat dikatakan bahwa perkawinan tidak hanya mementingkan aspek perdata (hanya sebagai perikatan), tetapi juga menyinggung aspek lain, seperti aspek biologis, aspek rohani, maupun aspek relegius. Berbeda misalnya dengan ketentuan yang terdapat dalam Pasal 26 Kitab Undang-undang Hukum Perdata (KUHPerdata), yang 
menentukan bahwa undang-undang memandang soal perkawinan hanya dalam hubungan-hubungan perdata.

Menurut Subekti (1994: 23), bahwa ketentuan ini hendak menyatakan suatu perkawinan yang sah, hanyalah perkawinan yang memenuhi syarat-syarat yang ditetapkan dalam KUHPerdata dan syarat-syarat serta peraturan agama dapat dikesampingkan, sehingga suatu perkawinan yang telah memenuhi syarat-syarat menurut KUHPerdata dan telah dicatatkan pada lembaga pencatat perkawinan, merupakan suatu perkawinan yang sah menurut hukum meskipun bertentangan dengan peraturan agama.

Pasal 1 UU No. 1 Tahun 1974, memberikan definisi mengenai apa yang harus diartikan dengan pengertian perkawinan, yaitu ikatan lahir bathin antara seorang pria dan seorang wanita sebagai suami isteri dengan tujuan membentuk keluarga (rumah tangga) yang bahagia kekal berdasarkan Ketuhanan Yang Maha Esa. Apabila definisi perkawinan tersebut di atas ditelaah, maka menurut Sudarsono (2005: 9-10), bahwa terdapat lima unsur di dalam perkawinan, yaitu:

1. Digunakannya kata "ikatan lahir bathin" mengandung arti bahwa dalam suatu perkawinan tidak hanya cukup dengan ikatan lahir saja atau ikatan bathin saja, tetapi kedua-duanya secara sinergi dan terpadu erat. Ikatan lahir merupakan ikatan yang dapat dilihat dan mengungkapkan hubungan hukum antara seorang pria dan wanita untuk hidup bersama sebagai suami istri (hubungan formal), sedangkan ikatan bathin merupakan hubungan yang non formal, sesuatu ikatan yang tidak tampak, tidak nyata, yang hanya dapat dirasakan oleh pihak-pihak yang mengikatkan dirinya. Ikatan bathin ini merupakan dasar ikatan lahir, sehingga dijadikan pondasi dalam pembentukan dan membina keluarga yang kekal dan bahagia.

2. Digunakannya kata ikatan "perkawinan hanya boleh terjadi antara seorang pria dan seorang wanita". Dengan demikian, undang-undang ini tidak melegalkan hubungan perkawinan antara pria dengan pria, wanita dengan wanita, atau antara waria dengan waria. Selain itu juga bahwa unsur ini mengandung asas perkawinan monogami (seorang pria dengan seorang wanita)

3. Digunakannya ungkapan "sebagai suami istri" mengandung arti bahwa menurut undang-undang, persekutuan antara seorang pria dengan wanita dipandang sebagai suami istri, apabila ikatan mereka didasarkan pada suatu perkawinan yang sah.

4. Dalam undang-undang disebutkan pula tujuan perkawinan yaitu untuk "membentuk keluarga (rumah tangga) yang bahagia dan kekal", artinya melarang perkawinan yang temporal atau sementara sebagaimana yang berlaku dalam perkawinan mut'ah. 
5. Berdasarkan "Ketuhanan Yang Maha Esa", menunjukkan bahwa perkawinan adalah peristiwa agama dan dilakukan untuk memenuhi perintah agama.

Berdasarkan penjelasan di atas, maka perkawinan tidak lagi dapat dipandang hanya sebagai hubungan individual antara pria (suami) pada satu sisi dengan wanita (isteri) pada sisi lainnya (dalam pengertian hubungan yang hanya bersifat keperdataan), tetapi harus dipandang sebagai ikatan suci (ikatan lahir bathin) yang didasarkan Ketuhanan Yang Maha Esa. Hal ini sesuai dengan pendapat Sidi Gazalba sebagaimana dikutip Mohd. Idris Ramulyo yang dijelaskan pada bab sebelumnya, dikatakan bahwa tidak merupakan perkawinan jika ikatan lahir bathin tersebut tidak bahagia atau perkawinan itu tidak kekal dan "tidak berdasarkan Ketuhanan Yang Maha Esa" (Mohd. Idris Ramulyo 1995: 44 dan 1996: 2). Berdasarkan uraian ini, maka dapat dikatakan bahwa fungsi pencatatan perkawinan memiliki hubungan dengan perlindungan hukum terhadap anak. Oleh sebab itu perlu dilakukan kajian yang bertujuan untuk mengetahui fungsi pencatatan perkawinan tersebut berhubungan dengan perlindungan terhadap anak baik sebelum ataupun sesudah adanya Putusan Mahkamah Konstitusi Nomor 46/PUU-VIII/2010.

\section{B. Metode Penelitian}

Penelitian ini akan mengkaji pokok permasalahan sesuai dengan ruang lingkup dan identifikasi masalah melalui pendekatan yuridis normatif. Dalam penelitian normatif ini penulis melakukan penelitian asas-asas hukum yang bertitik tolak dari bidang-bidang tata hukum tertentu, dengan cara mengadakan identifikasi terlebih dahulu terhadap kaidah-kaidah hukum yang telah dirumuskan di dalam perundang-undangan. Di dalam penelitian ini penulis mengamati terkait fungsi pencatatan perkawinan tersebut berhubungan dengan perlindungan terhadap anak baik sebelum ataupun sesudah adanya Putusan Mahkamah Konstitusi Nomor 46/PUU-VIII/2010.

Sifat penelitian ini adalah deskriptif, yang bertujuan untuk memberikan gambaran tentang gejala-gejala sosial yang terkait dengan masalah fungsi pencatatan perkawinan. Sumber data penelitian berupa bahan hukum primer, 
bahan hukum sekunder dan bahan hukum tersier. Metode pengumpulan data dilakukan menggunakan teknik studi dokumen, yang dianalisis dengan menggunakan teknik analisis kualitatif.

\section{Hasil Penelitian dan Analisis}

\section{Tujuan perkawinan dan syarat-syarat perkawinan}

Tujuan perkawinan menurut UU No. 1 Tahun 1974 dapat dilihat pada redaksi kalimat terakhir Pasal 1 yang menyebutkan bahwa “... dengan tujuan membentuk keluarga (rumah tangga) yang bahagia dan kekal berdasarkan Ketuhanan Yang Maha Esa”. Selanjutnya dalam Penjelasan Pasal 1, disebutkan pula bahwa sebagai Negara yang berdasarkan Pancasila, di mana Sila yang pertamanya ialah Ketuhanan Yang Maha Esa, maka perkawinan mempunyai hubungan yang erat sekali dengan agama/kerohanian.

Penjelasan Umum UU No 1. Tahun 1974 tersebut ada disebutkan bahwa tujuan perkawinan adalah membentuk keluarga yang bahagia dan kekal, sehingga suami isteri perlu saling membantu dan melengkapi, agar masing-masing dapat mengembangkan kepribadiannya membantu dan mencapai kesejahteraan sprituil dan material. Berhubung bahwa tujuan perkawinan adalah untuk membentuk keluarga yang bahagia kekal dan sejahtera, maka undang-undang ini menganut prinsip mempersukar terjadinya perceraian, harus ada alasan-alasan tertentu serta harus dilaksanakan di hadapan (depan) sidang pengadilan.

Berdasarkan ketentuan pada Pasal 1 dan berikut penjelasannya, serta Penjelasan Umum UU No. 1 Tahun 1974, maka dapat dijelaskan bahwa tujuan perkawinan adalah:

a. membentuk keluarga (rumah tangga) yang bahagia;

b. membentuk keluarga (rumah tangga) yang kekal;

c. membentuk keluarga (rumah tangga) yang didasarkan pada Ketuhanan Yang Maha Esa;

d. melanjutkan keturunan;

e. sarana pengembangan kepribadian pasangan suami isteri; dan

f. sarana mencapai kesejahteraan sprituil dan material. 
Berbeda halnya dengan UU No. 1 Tahun 1974, maka tujuan perkawinan yang disebutkan dalam Pasal 3 KHI, yaitu untuk mewujudkan kehidupan rumah tangga yang sakinah, mawaddah dan rahmah (Saekan dan Erniati Effendi 1997: 76). Memperhatikan ketentuan pada Pasal 1 UU No. 1 Tahun 1974 dan Pasal 3 KHI, sebenarnya terlihat ada persamaan tentang penyebutan tujuan perkawinan dalam kedua ketentuan tersebut, yaitu untuk membentuk rumah tangga (keluarga) yang bahagia, hanya saja dalam KHI lebih menggambarkan bahwa rumah tangga (keluarga) yang bahagia adalah rumah tangga yang sakinah, mawaddah dan rahmah (tenteram, cinta dan kasih sayang)

Konsepsi rumah tangga yang sakinah, mawaddah dan rahmah sebenarnya diadopsi dari Al-Qur'an dalam Surat Ar-Rum ayat 21 yang diartikan:

"Dan di antara keterangan-keterangan (kekuasaan) Tuhan, diciptakan-Nya untuk kamu pasangan (isteri) dari diri (bangsa) kamu sendiri, supaya kamu tenang (sakinah) bersama-sama dengan dia, dan dijadikannya cinta dan kasih sayang (mawaddah wa rahmah) di antara kamu, sesungguhnya hal yang demikian itu menjadi keterangan bagi kaum yang berpikir."

Berdasarkan konsepsi rumah tangga yang sakinah, mawaddah dan rahmah, maka tujuan utama dari perkawinan berdasarkan KHI adalah membentuk keluarga yang tenang lahir dan bathin, saling mencintai dan saling mengasihi dalam keluarga (Salmi Abbas 2003: 61).

Menurut pandangan Imam Ghazali sebagaimana dikutip Mohd. Idris Ramulyo (1996: 27), dikatakan bahwa tujuan dan faedah perkawinan terdiri dari 5 (lima) hal, sebagai berikut:

a. Memperoleh keturunan yang sah yang akan melangsungkan keturunan serta memperkembangkan suku-suku bangsa manusia;

b. Memenuhi tuntutan hidup naluriah kemanusiaan;

c. Memelihara manusia dari kejahatan dan kerusakan;

d. Membentuk dan mengatur rumah tangga yang menjadi basis pertama dari masyarakat yang besar di atas dasar kecintaan dan kasih sayang;

e. Menumbuhkan kesungguhan berusaha mencari rezeki penghidupan yang halal dan memperbesar rasa tanggung jawab. 
Pandangan lain dari M. Yunus (1991: 1), dikatakan bahwa tujuan perkawinan ialah menurut perintah Allah untuk memperoleh keturunan yang sah dalam masyarakat, dengan mendirikan rumah tangga yang damai dan teratur. Sedangkan menurut Sayyid Sabiq (1998: 9), dijelaskan bahwa perkawinan merupakan suatu cara yang dipilih Allah sebagai jalan bagi manusia untuk beranak, berkembang biak dan kelestarian hidupnya, setelah masing-masing pasangan siap melakukan peranannya yang positif dalam mewujudkan tujuan perkawinan.

Demikian pula menurut pendapat A. Rahman I Doi (1996: 206), dijelaskan bahwa tujuan perkawinan yang paling besar adalah beribadah kepada Allah. Ibadah disini tidak hanya berarti upacara ritual belaka, seperti hubungan kelamin suami isteri melainkan pada hakekatnya mencakup berbagai amal yang baik dalam seluruh aspek kehidupan.

Berbicara mengenai syarat sah perkawinan, maka pertama sekali harus merujuk pada ketentuan yang terdapat dalam Pasal 2 UU No. 1 Tahun 1974. yang menentukan bahwa sahnya perkawinan jika dilaksakan menurut agama dan kepercayaan orang-orang yang melangsungkan perkawinan tersebut, serta harus pula dicatatkan. Dengan demikian, sahnya perkawinan tetap harus didasarkan pada hukum (ajaran agama), selain syarat yang diatur dalam UU No. 1 Tahun 1974 (menurut hukum negara).

Syarat perkawinan berdasarkan UU No. 1 Tahun 1974 dapat dibedakan dalam 2 (dua) jenis, yaitu syarat materil dan syarat formil. Sedangkan syarat materil juga masih dapat dibedakan dalam dua jenis, yaitu syarat materil absolut dan syarat materil yang relatif. Syarat materil adalah syarat yang mengenai atau berkaitan dengan diri pribadi seseorang yang akan melangsungkan perkawinan yang harus dipenuhi untuk dapat melangsungkan perkawinannya, sedangkan syarat formil adalah syarat yang berkaitan dengan tata cara (prosedur) untuk melangsungkan perkawinan (Sudarsono 2005: 41-42).

Syarat materil absolut merupakan syarat yang harus dipenuhi oleh setiap orang (calon pasangan suami isteri) yang akan melangsungkan perkawinan. Syarat ini melekat (ada) pada diri individu setiap calon pasangan suami isteri tanpa 
memandang dengan siapa dia akan melangsungkan perkawinannya, yang terdiri dari:

a. persetujuan dari kedua calon mempelai;

b. dalam hal calon mempelai belum genap berusia 21 tahun, maka harus ada izin dari orang tua, atau izin dari salah satu orang jika salah satu dari orang tua telah meninggal dunia atau diletakkan di bawah pengampuan, atau izin dari wali atau orang yang memelihara atau keluarga yang mempunyai hubungan darah dalam garis keturunan lurus ke atas selama mereka masih hidup dan dalam keadaan dapat menyatakan kehendaknya;

c. izin dari pengadilan dalam daerah hukum tempat tinggal orang yang akan melangsungkan perkawinan, dalam hal adanya perbedaan pendapat dari orangorang yang tersebut pada angka 2 tersebut di atas; dan

d. calon mempelai pria harus sudah mencapai umur 19 tahun dan calon mempelai wanita harus sudah mencapai umur 16 tahun.

Syarat materil relatif merupakan syarat yang tidak berlaku umum pada setiap pribadi seseorang (individu) yang akan melangsungkan perkawinan, tetapi hanya melekat pada pribadi seorang tertentu yang dilarang kawin karena adanya larangan perkawinan bagi dirinya atau larangan bagi seseorang untuk mengawini seseorang tertentu. Syarat materil relatif ini diatur dalam Pasal 8 sampai dengan Pasal 11 UU No. 1 Tahun 1974, yang terdiri dari:

a. perkawinan dilarang antara dua orang yang:

1) berhubungan darah dalam garis keturunan lurus ke bawah ataupun ke atas;

2) berhubungan darah dalam garis keturunan menyamping yaitu antara saudara, antara seorang dengan saudara orang tua dan antara seorang dengan saudara neneknya;

3) berhubungan semenda, yaitu mertua, anak tiri menantu dan ibu/bapak tiri;

4) berhubungan susuan, yaitu orang tua susuan, anak susuan, saudara susuan dan bibi/paman susuan;

5) berhubungan saudara dengan isteri atau sebagai bibi atau kemenakan dari isteri, dalam hal seorang suami beristeri lebih dari seorang; 
6) mempunyai hubungan yang oleh agamanya atau peraturan lain yang berlaku, dilarang kawin.

b. perkawinan dilarang apabila orang tersebut yang masih terikat tali perkawinan dengan orang lain, kecuali bagi seorang pria dapat kawin lagi (berpoligami) jika telah mendapat izin dari pengadilan atas permintaan pihak-pihak yang bersangkutan dengan alasan bahwa isterinya tidak dapat menjalankan kewajibannya sebagai isteri; atau isteri mendapat cacat badan atau penyakit yang tidak dapat disembuhkan; atau isteri tidak dapat melahirkan keturunan.

c. perkawinan dilarang bagi apabila kedua calon mempelai tersebut sebelumnya pernah sebagai pasangan suami dan isteri dan sudah dua kali kawin cerai, kecuali hukum masing-masing agama dan kepercayaannya itu dari yang bersangkutan tidak menentukan lain.

d. seorang wanita yang perkawinannya terputus baik karena perceraian maupun karena suaminya meninggal dunia dilarang untuk melangsungkan perkawinan lagi dengan pria lainnya sebelum dirinya melewati masa jangka waktu tunggu (masa iddah), yaitu:

1) selama 130 (seratus tiga puluh) hari, apabila perkawinan putus karena suami meninggal dunia.

2) selama 3 (tiga) kali suci bagi yang masih berdatang bulan atau dengan sekurang-kurangnya 90 hari dan bagi yang tidak berdatang bulan ditetapkan 90 hari, apabila perkawinan putus karena perceraian.

3) sampai melahirkan, apabila perkawinan terputus pada saat dirinya dalam keadaan hamil.

Syarat formil dalam perkawinan adalah syarat yang berhubungan dengan prosedur atau tata cara untuk melangsungkan perkawinan, yang harus dipenuhi para pihak sebelum perkawinan berlangsung. Syarat formil ini diatur secara khusus dalam Peraturan Pemerintah Nomor 9 Tahun 1975 tentang Pelaksanaan Undang-undang Nomor 1 Tahun 1974 tentang Perkawinan (selanjutnya disingkat PP No. 9 Tahun 1975), serta beberapa aturan pelaksana lainnya yang hanya berlaku karena status seseorang sebagai anggota dari suatu instansi tertentu, seperti: 
a. Peraturan Pemerintah Nomor 10 Tahun 1983 tentang Izin Perkawinan dan Perceraian bagi Pegawai Negeri Sipil;

b. Keputusan Menteri Pertahanan Keamanan/Panglima Angkatan Bersenjata Tanggal 3 Januari 1980 Nomor: Kep/01/I/1980 tentang Peraturan Perkawinan, Perceraian dan Rujuk Anggota ABRI;

c. Petunjuk Teknis Kepala Kepolisian Republik Indonesia Tanggal 31 Maret 1981 Nomor: POL/JUKNIS/01/III/1981 tentang Perkawinan, Perceraian dan Rujuk Anggota POLRI;

d. Peraturan Jaksa Agung Tanggal 19 Mei 1982 Nomor: PER/001/JA/5/1982 tentang Perkawinan dan Perceraian Karyawan Kejaksaan Republik Indonesia.

Syarat formil ini sekaligus merupakan tata cara perkawinan yang harus ditempuh oleh para pihak yang berkepentingan sebelum dan pada saat dilangsungkan perkawinan, yang berdasarkan PP No. 9 Tahun 1975 meliputi tahap-tahap sebagai berikut:

a. Setiap orang yang akan melangsungkan perkawinan memberitahukan kehendak kepada Pegawai Pencatat ditempat perkawinan akan dilangsungkan. Pemberitahuan dilakukan sekurang-kurangnya 10 (sepuluh) hari kerja sebelum perkawinan dilangsungkan. Pengecualian terhadap jangka waktu, karena sesuatu alasan yang penting, diberikan oleh Camat atas nama Bupati.

b. Pemberitahuan dilakukan secara lisan atau tertulis oleh calon mempelai, atau oleh orang tua atau wakilnya, yang memuat nama, umur, agama/kepercayaan, pekerjaan, tempat kediaman calon mempelai dan apabila salah seorang atau keduanya pernah kawin, disebutkan juga nama isteri atau suaminya terdahulu.

c. Pegawai Pencatat yang menerima pemberitahuan kehendak melangsungkan perkawinan, meneliti apakah syarat-syarat perkawinan telah dipenuhi dan apakah tidak terdapat halangan perkawinan menurut UU No. 1 Tahun 1974. Selain itu, Pegawai Pencatat meneliti pula:

1) kutipan akta kelahiran atau surat kenal lahir calon mempelai. Dalam hal tidak ada akta kelahiran atau surat kenal lahir, dapat dipergunakan surat keterangan yang menyatakan umur dan asal-usul calon mempelai yang diberikan oleh Kepala Desa atau yang setingkat dengan itu; 
2) keterangan mengenai nama, agama/kepercayaan, pekerjaan dan tempat tinggal orang tua calon mempelai;

3) izin tertulis/izin Pengadilan sebagai dimaksud dalam Pasal 6 ayat (2), (3), (4) dan (5) UU No. 1 Tahun 1974, apabila salah seorang calon mempelai atau keduanya belum mencapai umur 21 (dua puluh satu) tahun;

4) izin Pengadilan sebagai dimaksud Pasal 4 UU No. 1 Tahun 1974 dalam hal calon mempelai adalah seorang suami yang masih mempunya isteri;

5) dispensasi Pengadilan/Pejabat sebagai dimaksud Pasal 7 ayat (2) Undang UU No. 1 Tahun 1974;

6) surat kematian isteri atau suami yang terdahulu atau dalam hal perceraian surat keterangan perceraian, bagi perkawinan untuk kedua kalinya atau lebih;

7) izin tertulis dari Pejabat yang ditunjuk oleh Menteri HANKAM/ PANGAB, apabila salah seorang calon mempelai atau keduanya anggota Angkatan Bersenjata; dan

8) Surat kuasa otentik atau di bawah tangan yang disahkan oleh Pegawai Pencatat, apabila salah seorang calon mempelai atau keduanya tidak dapat hadir sendiri karena sesuatu alasan yang penting, sehingga mewakilkan kepada orang lain.

d. Hasil penelitian yang dilakukan Pegawai Pencatat ditulis dalam sebuah daftar yang diperuntukkan untuk itu. Apabila ternyata dari hasil penelitian terdapat halangan perkawinan sebagai dimaksud UU No. 1 Tahun 1974 dan atau belum dipenuhinya persyaratan tersebut dalam Pasal 6 ayat (2) Peraturan Pemerintah ini, keadaan itu segera diberitahukan kepada calon mempelai atau kepada orang tua atau kepada wakilnya.

e. Setelah dipenuhinya tata cara dan syarat-syarat pemberitahuan dan tidak adanya sesuatu halangan perkawinan, Pegawai Pencatat menyelenggarakan pengumuman tentang pemberitahuan kehendak melangsungkan perkawinan dengan cara menempelkan surat pengumuman menurut formulir yang ditetapkan pada kantor Pencatatan Perkawinan pada suatu tempat yang sudah ditentukan dan mudah dibaca oleh umum. 
f. Pengumuman ditandatangani oleh Pegawai Pencatat dan memuat:

1) nama, umur, agama/kepercayaan, pekerjaan, tempat kediaman dari calon mempelai dan dari orang tua calon mempelai; apabila salah seorang atau keduanya pernah kawin disebutkan nama isteri dan atau suami mereka terdahulu; dan

2) hari, tanggal, jam dan tempat perkawinan akan dilangsungkan.

g. Perkawinan dilangsungkan setelah hari kesepuluh sejak pengumuman kehendak perkawinan oleh Pegawai Pencatat dan tata cara perkawinan dilakukan menurut hukum masing-masing agama dan kepercayaan yang melangsungkan perkawinan serta dilaksanakan dihadapan Pegawai Pencatat dan dihadiri oleh dua orang saksi.

h. Sesaat sesudah dilangsungkannya perkawinan, kedua mempelai menandatangani akta perkawinan yang telah disiapkan oleh Pegawai Pencatat berdasarkan ketentuan yang berlaku. Akta perkawinan yang telah ditandatangani oleh mempelai itu, selanjutnya ditandatangani pula oleh kedua saksi dan Pegawai Pencatat yang menghadiri perkawinan dan khusus bagi yang melangsungkan perkawinan menurut agama Islam, ditandatangani pula oleh wali nikah atau yang mewakilinya. Sejak penandatanganan akta perkawinan, maka perkawinan telah tercatat secara resmi.

\section{Akibat hukum perkawinan terhadap anak}

UU No. 1 Tahun 1974 tidak hanya mengatur tentang perkawinan, tetapi juga mengatur masalah hukum yang termasuk dalam lapangan hukum keluarga, seperti hubungan harta benda (kekayaan) antara suami isteri dalam perkawinan, kedudukan anak dalam keluarga, hubungan hukum antara orang tua dengan anak (hak dan kewajiban orang tua terhadap anak) dan termasuk pula masalah perwalian. Seperti yang dikatakan Subekti, bahwa hukum kekeluargaan adalah hukum yang mengatur hubungan-hubungan hukum yang timbul dari hubungan kekeluargaan, yaitu perkawinan dan hubungan dalam lapangan hukum kekayaan antara suami isteri (Subekti 1994: 16).

Khusus terkait dengan anak, maka akibat perkawinan terhadap anak yang dilahirkan dari perkawinan yang sah akan menimbulkan hubungan hukum atau 
menimbulkan hak dan kewajiban antara orang tua dan anak secara timbal balik, yang pengaturannya terdapat dalam Pasal 45 sampai dengan Pasal 49 UU No. 1 Tahun 1974. Adapun hubungan hukum antara orang tua dan anak, sebagai berikut:

a. kedua orang tua wajib memelihara dan mendidik anak-anak mereka sebaikbaiknya, dan kewajiban ini berlaku sampai anak itu kawin atau dapat berdiri sendiri, bahkan kewajiban ini berlaku terus walaupun perkawinan antara kedua orang tua putus.

b. anak wajib menghormati orang tua dan mentaati kehendak mereka yang baik.

c. jika anak telah dewasa, ia wajib memelihara orang tua dan keluarga dalam garis lurus ke atas menurut kemampuannya, jika mereka memerlukan bantuan.

d. anak yang belum mencapai umur 18 (delapan belas) tahun atau belum pernah melangsungkan perkawinan ada di bawah kekuasaan orang tuanya selama mereka tidak dicabut dari kekuasaannya.

e. orang tua mewakili anak mengenai segala perbuatan hukum di dalam dan di luar pengadilan.

f. orang tua tidak diperbolehkan memindahkan hak atau menggadaikan barangbarang tetap yang dimiliki anaknya yang belum berumur 18 (delapan belas) tahun atau belum pernah melangsungkan perkawinan, kecuali jika kepentingan anak itu menghendaki.

g. salah seorang atau kedua orang tua dapat dicabut kekuasaannya terhadap seorang anak atau lebih untuk waktu yang tertentu atas permintaan orang tua yang lain, keluarga anak dalam garis lurus ke atas dan saudara kandung yang telah dewasa atau pejabat yang berwenang, dengan keputusan pengadilan dalam hal-hal: sangat melalaikan kewajibannya terhadap anaknya dan berkelakuan buruk sekali; dan walaupun orang tua dicabut kekuasaannya, mereka masih tetap berkewajiban untuk memberi biaya pemeliharaan kepada anak tersebut.

3. Konsekuensi yuridis terhadap fungsi pencatatan perkawinan setelah keluarnya putusan Mahkamah Konstitusi Nomor: 46/PUU-VIII/2010

Pencatatan perkawinan sebagai suatu peristiwa penting yang merupakan kewajiban yang harus dilakukan oleh masyarakat yang akan melangsungkan 
perkawinan. Kewajiban pencacatan perkawinan dapat dilihat pada Pasal 2 ayat (2) UU No. 1 Tahun 1974, dan dalam Penjelasan Umum UU No. 1 Tahun 1974 ditentukan bahwa pencatatan perkawinan ini merupakan salah satu asas dalam undang-undang UU No. 1 Tahun 1974 dan menyebutkan bahwa pencacatan tiaptiap perkawinan adalah sama halnya dengan pencatatan peristiwa-peristiwa penting dalam kehidupan seseorang.

Pencatatan perkawinan merupakan kewajiban yang harus dilaksanakan oleh seseorang yang telah melangsungkan perkawinan, karena berdasarkan Pasal 3 UU No. 23 Tahun 2006 ditegaskan bahwa setiap penduduk wajib melaporkan peristiwa kependudukan dan peristiwa penting yang dialaminya kepada Instansi Pelaksana dengan memenuhi persyaratan yang diperlukan dalam Pendaftaran Penduduk dan Pencatatan Sipil. Selanjutnya berdasarkan Pasal 2 Perpres No. 25 Tahun 2008, ditegaskan bahwa pendaftaran penduduk dan pencatatan sipil bertujuan untuk memberikan keabsahan identitas dan kepastian hukum atas dokumen penduduk, perlindungan status hak sipil penduduk, dan mendapatkan data yang mutakhir, benar dan lengkap.

Memperhatikan ketentuan-ketentuan di atas, maka perkawinan dengan pencatatan perkawinan merupakan 2 (dua) peristiwa yang berbeda, sehingga masalah keabsahan perkawinan tidak tergantung kepada persoalan pencatatan perkawinan. Sahnya perkawinan apabila perkawinan tersebut dilaksanakan menurut agama atau kepercayaan, dengan demikian jika menurut agama suatu perkawinan adalah sah, maka perkawinan tersebut sah secara yuridis.

Pencatatan perkawinan merupakan kewajiban untuk dilaksanakan, tidak menjadi ukuran sah atau tidak sahnya perkawinan, karena berdasarkan Pasal 2 Perpres No. 25 Tahun 2008, pencatatan sipil hanya bertujuan untuk memberikan "keabsahan identitas" dan "kepastian hukum atas dokumen penduduk", "perlindungan status hak sipil penduduk", dan "mendapatkan data yang mutahir, benar dan lengkap", jadi tidak untuk menjadi ukuran atau alasan sahnya perkawinan (Tengku Erwinsyahbana 2012: 330).

Ketentuan Pasal 2 UU No. 1 Tahun 1974 menentukan dua pendapat yang berbeda. Pendapat pertama mengatakan bahwa Pasal 2 ayat (1) dan Pasal 2 ayat 
(2) UU No. 1 Tahun 1974, merupakan hal yang berbeda dan terpisah, berarti perkawinan sah jika telah dilaksanakan menurut agama dan kepercayaannya, sedangkan pencatatan perkawinan hanya sebagai persyaratan administrasi saja. Pendapat kedua, mengatakan bahwa ketentuan Pasal 2 ayat (1) dan Pasal 2 ayat (2) UU No. 1 Tahun 1974, merupakan ketentuan yang bersifat kumulatif bukan alternatif.

Mahkamah Konstitusi melalui Putusan Mahkamah Konstitusi Nomor: 46/PUU-VIII/2010, menafsirkan bahwa sahnya perkawinan hanya di dasarkan hukum agama, sementara pencatatan perkawinan hanya merupakan persyaratan administrasi saja, yang berarti tidak merupakan syarat sah perkawinan. Berdasarkan pertimbangan ini, maka pencatatan perkawinan tidak merupakan syarat sah suatu perkawinan, karena syarat sah perkawinan adalah sesuai syarat atau ketentuan yang terdapat dalam ajaran agama, tetapi pencatatan perkawinan mutlak harus dilaksanakan demi melindungi hak-hak para pihak dalam satu keluarga, yang terdiri dari suami, isteri dan anak yang dilahirkan dari perkawinan itu.

Melalui pencatatan perkawinan yang diikuti dengan terbitnya buku nikah, akan dapat membuktikan bahwa seseorang memang benar sedang terikat dalam satu ikatan perkawinan, sehingga para pihak dapat menuntut hak-haknya dan dituntut untuk memenuhi kewajibannya yang tertuang dalam UU No. 1 Tahun 1974. Dengan demikian, pencatatan perkawinan dilakukan bukan bertujuan untuk membuktikan sahnya perkawinan dalam pengertian sah menurut agama, tetapi semata-mata hanya sebagai pengakuan (legalisasi) dari negara bahwa para pihak dalam perkawinan memang benar terikat dalam suatu ikatan perkawinan, dengan kata lain untuk membuktikan identitas diri seseorang bahwa dirinya adalah benar suami atau isteri dari seseorang, serta untuk membuktikan status seorang anak sebagai anak dari pasangan suami isteri (Tengku Erwinsyahbana 2012: 330).

4. Perspektif perlindungan hukum terhadap anak akibat perkawinan tidak tercatatkan setelah keluarnya putusan Mahkamah Konstitusi Nomor: 46/PUU-VIII/2010

Pencatatan perkawinan harus dilakukan oleh setiap pasangan suami isteri, tetapi sejak berlakunya Putusan Mahkamah Konstitusi Nomor 46/PUU-VIII/2010, 
tidak berarti bahwa tanpa adanya pencatatan perkawinan, maka anak akan kehilangan hak-hak perdata dari ayah biologisnya. Putusan Mahkamah Konstitusi Nomor 46/PUU-VIII/2010, merupakan putusan hasil uji materil terhadap Pasal 43 UU No. 1 Tahun 1974 yang diajukan oleh Aisyah (Machica Mokhtar), pasangan yang dinikahi siri oleh Moerdiono, yang walaupun pernikahannya secara siri (tidak dicatatkan di lembaga pencatatan perkawinan), tetapi pernikahan secara sah telah dilaksanakan menurut ajaran agama Islam, sehingga pernikahan tersebut tidak dapat dikelompokan sebagai pasangan yang melakukan perzinahan.

Sebelum adanya Putusan Mahkamah Konstitusi Nomor: 46/PUUVIII/2010, anak-anak yang dilahirkan dari hasil nikah siri, status hukumnya sama dengan anak luar kawin hasil zinah, yakni hanya punya hubungan hukum dengan ibunya. Hal ini membawa konsekuensi, anak yang lahir dari kawin siri dan juga zinah, secara hukum negara tidak mempunyai hubungan hukum dengan ayahnya.

Dalam akta kelahiran anak yang lahir dari perkawinan siri tercantum bahwa telah dilahirkan seorang anak bernama ..., hari ..., dan tanggal kelahiran ..., urutan kelahiran, nama ibu dan tanggal kelahiran ibu (menyebut nama ibu saja, tidak menyebut nama ayah si anak). Hal ini diatur dalam Pasal 55 ayat (2) huruf a PP No. 37 Tahun 2007.

Konsekuensi dari tidak adanya hubungan antara ayah dan anak secara hukum, juga berakibat anak luar kawin tidak mendapat warisan dari ayah biologisnya, tetapi Mahkamah Konstitusi melalui Putusan Mahkamah Konstitusi No.46/PUU-VIII/2010, menyatakan anak yang lahir di luar kawin mempunyai hubungan hukum dengan ayah biologis, tidak lagi hanya kepada ibu dan keluarga ibu.

Implikasi putusan Mahkamah Konstitusi tersebut tentunya memiliki implikasi positif dan negatif. Dikatakan positif ketika para pelaku nikah siri dan zinah mendapatkan haknya untuk mewaris, sedangkan sisi negatifnya bahwa hal ini merusak tatanan hukum yang telah lama dilaksanakan. Dampak positif Putusan Mahkamah Konstitusi Nomor 46/PUU-VIII/2010, terlihat dari penyataan yang menyebutkan bahwa Pasal 43 ayat (1) UU No. 1 Tahun 1974 adalah bertentangan dengan UUD 1945 dan tidak memiliki kekuatan hukum mengikat sepanjang 
dimaknai menghilangkan hubungan perdata dengan laki-laki yang dapat dibuktikan berdasarkan ilmu pengetahuan dan teknologi dan/atau alat bukti lain menurut hukum ternyata mempunyai hubungan darah sebagai ayahnya, sehingga ayat tersebut harus dibaca, "anak yang dilahirkan di luar perkawinan mempunyai hubungan perdata dengan ibunya dan keluarga ibunya, serta dengan laki-laki sebagai ayahnya yang dapat dibuktikan berdasarkan ilmu pengetahuan dan teknologi dan/atau alat bukti lain menurut hukum mempunyai hubungan darah, termasuk hubungan perdata dengan keluarga ayahnya".

Dampak negatif Putusan Mahkamah Konstitusi Nomor 46/PUU-VIII/2010 dapat dinilai melanggar ajaran Islam dan tatanan hukum Islam, apabila ada persepsi bahwastatus anak di luar nikah disamakan dengan status anak zinah, yang mempunyai akibat hukum: (a) tidak ada hubungan nasab dengan bapaknya, anak hanya mempunyai hubungan nasab dengan ibunya, dan bapaknya tidak wajib memberikan nafkah kepada anak tersebut, walaupun secara biologis tetap merupakan anaknya, jadi hubungan yang timbul hanyalah secara manusiawi, bukan secara hukum; (2) tidak ada hak saling mewaris dengan bapaknya, karena hubungan nasab merupakan salah satu penyebab kewarisan; (3) bapak tidak dapat menjadi wali bagi anak di luar nikah, dan apabila anak di luar nikah itu kebetulan seorang perempuan dan sudah dewasa lalu akan menikah, maka ia tidak berhak dinikahkan oleh bapak biologisnya.

Selain dampak negatif seperti dijelaskan di atas, maka Putusan Mahkamah Konstitusi Nomor 46/PUU-VIII/2010, yang jika dilihat sisi praktisi notaris yang berwenang untuk membuat suatu keterangan waris, hal ini agak merepotkan, karena untuk membuat suatu keterangan waris diharuskan untuk menerima buktibukti autentik berupa akta kelahiran yang menyatakan bahwa anak tersebut merupakan anak sah dari hasil perkawinan kedua orangtuanya. Ada kekhawatiran di dalam praktek di masyarakat, tiba-tiba akan bermunculan berbagai kasus sehubungan dengan adanya tuntutan dari anak-anak luar nikah yang tidak/belum pernah diakui pewaris, yang menuntut bagian dari warisan tersebut.

Putusan Mahkamah Konstitusi dapat dikatakan mencerminkan prinsip persamaan di hadapan hukum (equality before the law) sebagaimana dimaksud 
dalam Pasal 28D ayat (1) yang menentukan bahwa setiap orang berhak atas pengakuan, jaminan, perlindungan, dan kepastian hukum yang adil, serta perlakuan yang sama di hadapan hukum. Hukum harus memberi perlindungan dan kepastian hukum yang adil terhadap status setiap anak yang dilahirkan dan hakhak yang ada padanya, termasuk terhadap anak yang dilahirkan di luar perkawinan yang sah menurut peraturan perundang-undangan.

Substansi dari Putusan Mahkamah Konstitusi No. 46/PUU-VIII/2010 tidak bermaksud memberikan peluang bagi seseorang untuk melakukan perzinahan lalu dengan mudah mereka mensahkan anak yang dilahirkan akibat zinah dengan merujuk pada Putusan Mahkamah Konstitusi tersebut, tetapi Mahkamah Konstitusi selain ingin mewujudkan keadilan hukum, juga ingin melindungi hakhak anak terhadap keadilannya.

Berbagai kalangan masyarakat khususnya Majelis Ulama Indonesia tidak setuju dengan putusan ini, karena jika putusan ini untuk status anak luar nikah dalam konteks nikah siri (nikah yang tidak didaftarkan tetapi menurut agama sah), dalam implementasi dapat meluas jika hubungan keperdataan yang dimaksudkan termasuk pula hubungan perdata yang timbul karena perzinahan dan dikhawatirkan adanya penyelewengan hukum terhadap ibu yang melahirkan anak luar nikah hasil zinah yang tidak dinikahi, lalu ingin disahkan. Pokok permasalahan hukum mengenai anak yang dilahirkan di luar perkawinan adalah mengenai makna hukum (legal meaning) pada frasa "yang dilahirkan di luar perkawinan" perlu memperoleh jawaban dalam perspektif yang lebih luas dan perlu pula dijawab permasalahan terkait, yaitu permasalahan tentang sahnya anak.

Kajian perspektif yuridis menyebutkan tidak tepat dan tidak adil jika hukum menetapkan bahwa anak yang lahir dari suatu kehamilan karena hubungan seksual di luar perkawinan hanya memiliki hubungan dengan perempuan tersebut sebagai ibunya, dan tidak tepat dan tidak adil pula jika hukum membebaskan lakilaki yang melakukan hubungan seksual yang menyebabkan terjadinya kehamilan dan kelahiran anak tersebut dibebaskan dari tanggungjawabnya sebagai seorang bapak dan bersamaan dengan itu hukum meniadakan pula hak-hak anak terhadap lelaki tersebut sebagai bapaknya. 
Anak merupakan karunia dari tuhan yang wajib dijaga dan dilindungi oleh kedua orang tua biologisnya dan hukum negara tempat dimana anak tersebut dilahirkan. Pengakuan negara mengenai perlindungan dan penghormatan terhadap hak-hak anak ditandai dengan lahirnya UU No. 39 Tahun 1999 dan UU No. 23 Tahun 2002, yang mempertegas bahwa hak-hak anak sebagai salah satu bagian dari prinsip-prinsip hak asasi manusia, sehingga dimasukkanlah hak anak ke bagian hak asasi manusia.

Kenyataan dalam praktiknya, sebagian besar undang-undang di Indonesia hanya mengatur mengenai perlindungan hak-hak anak yang mengacu pada anakanak yang dilahirkan akibat adanya suatu pernikahan yang sah menurut hukum negara, sehingga terjadi pembedaan terhadap anak yang lahir dari hasil pernikahan yang tidak diakui oleh hukum negara atau yang sering di anggap sebagai anak yang tidak sah menurut hukum negara. Akibat hukum dari kebijakan diskriminatif ini maka secara hukum anak hanya mempunyai hubungan perdata hanya terhadap ibu biologisnya saja, sedangkan terhadap ayah biologisnya anak tidak dapat menuntut apa-apa, karena itu secara yuridis tidak diakui mempunyai hubungan perdata dengan ayah bilogisnya.

Mengingat keluarnya Putusan Mahkamah Konstitusi Nomor: 46/PUUVIII/2010, maka anak harus diakui mempunyai hubungan nasab dengan ibunya dan keluarga ibunya, serta dengan ayah dan keluarga ayahnya, sehingga ayahnya dan keluarga ayahnya wajib memberikan nafkah terhadap anak tersebut. Pokok pikiran utama yang melandasi Putusan Mahkamah Konstitusi terhadap ketentuan Pasal 43 ayat (1) UUP pada dasarnya adalah "tidak tepat" dan "tidak adil" jika hukum membebaskan laki-laki yang melakukan hubungan seksual yang menyebabkan terjadinya kehamilan dan kelahiran anak tersebut dari tanggung jawabnya sebagai seorang bapak dan bersamaan dengan itu hukum meniadakan hak-hak anak terhadap laki-laki tersebut sebagai ayah, padahal pernikahannya sah secara hukum agama.

Permasalahan perlindungan hukum terhadap hak-hak anak yang lahir dari perkawinan tidak tercatatkan sudah terjawab dengan terbitnya Putusan Mahkamah Konstitusi Nomor: 46/PUU-VIII/2010, karena berdasarkan putusan ini ditentukan 
bahwa anak yang dilahirkan di luar perkawinan mempunyai hubungan perdata dengan ibunya dan keluarga ibunya, serta dengan laki-laki sebagai ayah biologisnya yang dapat dibuktikan berdasarkan ilmu pengetahuan dan teknologi dan/atau alat bukti lain menurut hukum mempunyai hubungan darah, termasuk hubungan perdata dengan keluarga ayahnya.

\section{Simpulan dan Saran}

\section{Simpulan}

Berdasarkan hasil pembahasan di atas, maka dapat disimpulkan bahwa fungsi pencatatan perkawinan merupakan perbuatan administrasi berdasarkan peraturan perundang-undangan yang berlaku yang dilakukan oleh instasi yang berwewenang (Kantor Urusan Agama bagi yang beragama Islam dan Kantor Catatan Sipil bagi yang beragama selain Islam) yang ditandai dengan penerbitan akta nikah dan buku nikah untuk kedua mempelai.

Putusan Mahkamah Konstitusi Nomor 46/PUU-VIII/2010 berimplikasi terhadap perubahan nilai-nilai dalam masyarakat mengenai status dan hak-hak terhadap anak luar kawin. Putusan Mahkamah Konstitusi tersebut seperti dua sisi mata uang. Di satu sisi melindungi hak-hak anak luar kawin, tetapi di sisi lain putusan tersebut terkesan dapat melemahkan fungsi perkawinan dan dapat menyebabkan lembaga perkawinan menjadi kurang tidak sakral.

\section{Saran}

Sehubungan dengan pencatatan perkawinan dan perlindungan anak yang lahir dari perkawinan yang tidak tercatatkan masih terdapat permasalahan yuridis, maka disarankan agar pemerintah segera merevisi Pasal 2 ayat (2) UU No. 1 Tahun 1974 dan mengeluarkan kebijakan yang merumuskan tanpa pencatatan perkawinan anak tetap mempunyai hubungan perdata dengan ayah dan keluarga ayahnya. Kepada para pejabat Lembaga Pencatatan Perkawinan disarankan hendaknya membantu masyarakat dengan memberikan kemudahan-kemudahan dan tidak melakukan prosedur yang berbelit-belit dalam pelaksanaan pencatatan perkawinan. 


\section{DAFTAR PUSTAKA}

\section{Buku:}

Abdul Rahman I. Doi. 1996. Karakteristik Hukum Perkawinan Islam, Jakarta: Sri Gunting.

Ali Afandi. 1997. Hukum Waris, Hukum Keluarga, Hukum Pembuktian, Jakarta: Rineka Cipta, Cetakan Keempat.

Mahmud Yunus. 1979. Hukum Perkawinan dalam Islam, Jakarta: Hidakarya Agung, Cetakan Kedelapan.

Mahmud Yunus. 1991. Hukum Perkawinan dalam Islam, Jakarta: Hida Karya Agung.

Mohd. Idris Ramulyo. 1995. Hukum Perkawinan, Hukum Kewarisan, Hukum Acara Peradilan Agama dan Zakat Menurut Hukum Islam, Jakarta: Sinar Grafika.

Mohd. Idris Ramulyo. 1996. Hukum Perkawinan Islam, Suatu Analisis dari Undang-undang Nomor 1 Tahun 1974 dan Kompilasi Hukum Islam, Jakarta: Bumi Aksara.

Saekan dan Erniati Effendi. 1997. Sejarah Penyusunan Kompilasi Hukum Islam di Indonesia, Surabaya: Arkola.

Sayyid Sabiq. 1998. Fikih Sunnah 6, Bandung:Alma'arif, Alih Bahasa Moh. Thalib, Cetakan Kelimabelas.

Soediman Kartohadiprodjo. 1984. Pengantar Tata Hukum di Indonesia, Jakarta: Ghalia Indonesia.

Soerjono Soekanto dan Sri Mamudji. 2003. Penelitian Hukum Normatif, Suatu Tinjauan Singkat, Jakarta: RadaGrafindo Persada, Cetakan Keenam.

Soerjono Soekanto. 1986. Pengantar Penelitian Hukum, Jakarta: UI-Press, Cetakan Ketiga.

Subekti. 1994. Pokok-pokok Hukum Perdata, Jakarta: Intermasa, Cetakan Keduapuluh Enam.

Sudarsono. 2005. Hukum Perkawinan Nasional, Jakarta: Rineka Cipta.

Sulistyowati Sugondo.2005. Pokok-pokok Pikiran dan Paradigma Baru Catatan Sipil Nasional, Jakarta: Komnas HAM.

Wantjik Saleh, K. 1960. Hukum Perkawinan Indonesia, Jakarta: Ghalia Indonesia.

Wirjono Prodjodikoro. 1991. Hukum Perkawinan di Indonesia, Bandung: Sumur Bandung, Cetakan Kesembilan. 
Disertasi dan Jurnal:

Tengku Erwinsyahbana. 2012. "Perspektif Hukum Perkawinan Antar Agama yang Berkeadilan Dikaitkan dengan Politik Hukum Perkawinan Indonesia Dalam Rangka Pembangunan Hukum Keluarga Nasional", Disertasi, Bandung: Program Doktor Ilmu Hukum Pascasarjana Universitas Padjadjaran.

Salmi Abbas. 2003, "Perkawinan Berbeda Agama dalam Perspektif Hukum Islam", Media Hukum, Volume XII, Nomor-2. 


\section{BIODATA PENULIS}

$\begin{array}{ll}\text { Nama } & : \text { Atikah Rahmi } \\ \text { Pekerjaan } & : \text { Dosen Fakultas Hukum Universitas Muhammadiyah Sumatera } \\ & \text { Utara } \\ \text { Jabatan } & : \text { Lektor } \\ \text { Nomor HP } & : \text { 082164617373 } \\ \text { E-mail } & : \text { atikahrahmi@gmail.com } \\ \text { Alamat Kantor } & : \text { Jl. Kapten Muchtar Basri No. 3, Medan } \\ \text { Nama } & : \text { Sakdul } \\ \text { Pekerjaan } & : \text { Wiraswasta } \\ \text { Jabatan } & :- \\ \text { Nomor HP } & :- \\ \text { E-mail } & : \text { sakdul71@gmail.com } \\ \text { Alamat Kantor } & : \text { Labuhan Batu Utara }\end{array}$

